УДК 330.1

DOI: https://doi.org/10.26642/jen-2018-4(86)-25-33

\author{
Ye.Khaustova, Ph. D, Associate Professo \\ M.Denysenko, Doctor of Economic Sciences, Professor, \\ Kyiv National University of Technologies and Design (Ukraine, Kyiv)
}

\title{
Intellectual capital development and protection assessment for institutions of higher education in Eastern Ukraine
}

\begin{abstract}
Modern empirical research on intellectual capital (IC) is related to the establishment of the mutual influence between its components, as well as its impact on the performance of business entities. The purpose of the article is to compare the intellectual capital components and the interpretation of their dynamic influence on the IC development level of the institution of higher education (IHE) in the conditions of reduction of one of the IC components or a sharp drop in the volume of services rendered. Methodology. The development and protection investigation of the IC components provided a factor analysis (the main component method) of the key indicators of the IHE activity. Based on the normalized values of the input indicators and their weights, the integral index of development and protection for the IC components for a certain IHE was calculated based on the results of the factor load research. With the input parameters normalization, some of them could be zero, so in order to prevent the zero values of the integral index of development and protection of the individual component and the IC as a whole, normalized additive convolution was used for their calculations. To interpret their meanings, a scale was developed for assessing the different levels of the IC development and protection in the range from [-1 to 1].

Results. Under evacuation conditions, with a significant reduction in activity and a drop in productivity, the actual state of client capital development and protection depended on the ability of the university to recover or not to lose students. The level of human capital protection was determined by the ability to increase its level quickly at the expense of external resources, and the level of innovative capital protection - with the ability to restore or maintain the indicators of innovation and scientific activity. The values of integral indicators of development and protection as for the IC components fluctuated within [-0.9, 1] and correspond to real tendencies in the activity of the IHE after their forced territorial movement. But among the IHEs there was simultaneously the same (either positive or negative) dynamics of integral indicators of human and innovative capital. A similar pattern is confirmed by studies in the activities of industrial companies and financial institutions.
\end{abstract}

Practical implications. The proposed method for determining the IC development and protection level is universal and may take into account different indicator combinations depending on the management objectives of the IHE. In addition, due to the problem factors normalization including in the analysis of indicators with different units of measurement does not occur. As well as the use of relative indicators, it is possible to match their meaning for different scale of institutions activity. Value / originality. The method involves conducting a non-financial analysis of the IC components, and also is not based on subjective values of the indicators, which is typical for expert methods with a score scale.

Keywords: innovative capital; human capital; client capital; capital development; capital reduction; capital renewal; factor analysis.

Introduction. Negative processes in the Ukrainian economy are reflected in the activities of institutions of higher education (IHEs) as elements of the socio-economic system. The consequences of the demographic crisis and external migration were accompanied by socio-economic implications of external aggression that did not go beyond higher education. Proceeding the function of IHEs in the socio-economic system of the country, when assessing the intellectual capital (IC) development and protection it is expedient to take into account the possibility of reproducing their intellectual resources. In this regard, it is advisable to develop further methodological approaches to assessing the components of IHE intellectual capital.

The process of IC development and protection of institutions of higher education during the period of their activity renewal after moving from temporarily occupied territories of Ukraine was chosen as a research object. Given the need for such a move, it was accompanied by a complete loss and the need to restore the material and technical base, reducing by half the contingent of academic staff (AS) and students, as well as the loss of partially restorative intellectual resources (procedural guidelines of education processes, software products, information bases, image and business ties), etc.

The purpose of the article is to assess the components of the intellectual capital of a certain IHE and to compare it with others on the basis of determining the factors with a logical interpretation of their impact on the level of intellectual capital development and protection in the conditions of a sharp decline in productivity.

Literature review. Methodological approaches to assess the level of the IC development and protection were developed using the recommendations (Pedro Eu. Et al. (2018), the existing approaches to its assessment for 
industrial enterprises (Kozhushko, O. (2011).) and the classification of the IC components according to Edvinsson (2009). In addition, taking into account that human capital serves as an integral part of the IC, the development of the aggregate indicator calculation used human development assessment (Tutova OV, (2015). The source of data collection for analysis was the reports of the rectors of the investigated institutions.

Goals and methodology of the article. As a result of the fact that the values of the input $i$-indicators of a certain (client, human and innovative without processing) component of the IC of a certain IHE could fluctuate at relatively large intervals and have different measure units, they were linearly normalized [Herv'e Abdi, 2010] within $[-1,1]$ with the distribution between incentives (formula 1.1) and disincentives (formula 1.2):

$$
\begin{aligned}
& \tilde{x}_{i a}=2 \times \frac{x_{i a}-x_{i}^{\min }}{x_{i}^{\text {max }}-x_{i}^{\min }}-1 ; \\
& \tilde{x}_{i a}=2 \times \frac{x_{i}^{\text {max }}-x_{i a}}{x_{i}^{\text {max }}-x_{i}^{\text {min }}}-1 ;
\end{aligned}
$$

where $\tilde{x}_{i a}$ is the normalized value of the input $\mathrm{i}^{\text {th }}$ indicator for the observation period a; $x_{i a}$ - the base value of the input $\mathrm{i}^{\text {th }}$ indicator for the observation period $\mathrm{a} ; x_{i}^{\max }, x_{i}^{\min }$ respectively, the maximum and minimum value of the $\mathrm{i}^{\text {th }}$ indicator for all observation periods.

Next, using statistic software Statistica a factor analysis has been conducted by the method of the main components. According to its results, the input $i$-indicators are transformed into new $i y$-indicators with different factor loads for $y$-factors. Within the framework of a certain $m$-component of the IC on the basis of the maximum factor load for each $i y$-indicator, its weighting factor has been calculated (formula 2):

$$
d_{\text {iym }}=\frac{f_{\text {iym }} \times \operatorname{Var}_{i y m}}{\sum f_{\text {iym }} \times \operatorname{Var}_{\text {iym }}}
$$

where $d_{\text {iym }}$ is the weighted coefficient of the input $\mathrm{i}^{\text {th }}$ indicator with the maximum value of the factor load that entered into the $y$-factor (the main component) of the IC $m$-component, $i=\overline{1, n}, \sum d_{\text {iym }}=1$, where $n$ is input $i$ indicators of IC $m$-component; $f_{i y}$ - the maximum value of the factor load of the input i-indicator, which entered into the $y$-factor (the main component); $\operatorname{Var}_{i y}$ - fractions of the total variance of the $y$-factor (the main component), which grouped the input $i$-indicators of the IC $m$-component with factor loads bigger than 0.7 (with a strong correlation bond on the basis of Pearson).

The annual values of the development and protection integral indicator of a separate IC $m$-component of the IHE included the definition of indicators for the $i y$-indicators (for input $i$-indicators, grouped by $y$-factors with factor loads bigger than 0.7 (formulas 3.1-3.3):

$$
\begin{aligned}
& d_{\text {iyK }} \times K_{\text {і норм }} ; \\
& d_{\text {iyL }} \times L_{\text {і норм }} ; \\
& d_{\text {iyN }} \times N_{\text {і норм }} .
\end{aligned}
$$

where $d_{i y K}, d_{i y L}, d_{i y N}$ are the weight of the $i y$-indicator of the client, human and innovative IC $m$-component accordingly, $i=\overline{1, n}$, where $n$ is the number of $i$-indicators used to assess the IC $m$-component $\left(\sum d_{i y}=\right.$ 1); $K_{\mathrm{i} \text { norm }}, L_{\mathrm{i} \text { norm }}, N_{\mathrm{i} \text { norm }}$ - normalized values of input i-indicators of the client, human and innovative IC $m$ component respectively within $[-1,1]$.

With the normalization of the input i-indicators, some of them got zero values; therefore, a normalized additive convolution was used to calculate them in order to prevent the zero values of the integral indicators of the iindicators and, as a result, the integral index of development and protection of the individual m-component. Taking into account the above-mentioned, annual estimation of the integral index for a certain intellectual capital $\mathrm{m}$ component of a certain IHE was carried out within [-1.1] by formulas 4.1-4.3:

$$
\begin{aligned}
& \mathrm{I}_{K}=\sum_{i=1}^{n} d_{i y k} \times \mathrm{K}_{\text {і норм }} ; \\
& \mathrm{I}_{L}=\sum_{i=1}^{n} d_{i y l} \times L_{\text {i норм }} ; \\
& \mathrm{I}_{N}=\sum_{i=1}^{n} d_{i y h} \times N_{\text {i норм }} .
\end{aligned}
$$

where $\mathrm{I}_{K}, \mathrm{I}_{L}, \mathrm{I}_{N}$ - respectively development and protection integral indicators of the client, human and innovative components of the IC for a certain period for a certain IHE.

For the comparative analysis of the IC development and protection level among the analyzed institutions, the IC integral indicators have been determined for the years of observation. According to the factor analysis results by the main components method, the integral indices of the client $\mathrm{I}_{K}$, human $\mathrm{I}_{L}$ and the innovative $\mathrm{I}_{N}$ components of the IC for the years of observation separately for each IHE have been converted into new $m z$-indicators. For each $m z$-indicator (integral indicators $\mathrm{I}_{K}, \mathrm{I}_{L}$ та $\mathrm{I}_{N}$, grouped by $z$-components with factor loads bigger than 0.7 ) its weighting factor is calculated (formula 5):

$$
d_{z m}=\frac{f_{z m} \times \operatorname{Var}_{z m}}{\sum f_{z m} \times \operatorname{Var}_{z m}}
$$

where $d_{z m}$ - the weight of the integral indicator of the IC $m$-component with the maximum value of the factor load, which entered into the $z$-factor (the main component), where $m=\overline{1,3}$ - index of the IC component $\left(\sum d_{z m}=1\right) ; f_{z m}$ - the maximum value of the integral indicator factor load of the IC $m$-component, which entered 
into the $z$-factor (the main component); $\operatorname{Var}_{z m}$ is the fraction of the total dispersion of the $z$-factor (the main component), which grouped the integral indicators of the IC $m$-component with factor loads bigger than 0.7.

The calculation of the annual values of the integral indicator for each IHE provided the definition of indicators for the corresponding observation period (formulas 6.1-6.3):

$$
\begin{aligned}
& d_{z K} \times \mathrm{I}_{K} ; \\
& d_{z L} \times \mathrm{I}_{L} ; \\
& d_{z N} \times \mathrm{I}_{N} ;
\end{aligned}
$$

where $d_{z K}, d_{z L}, d_{z N}$ - the weight factor of the $m z$-indicator or the integral indeicator of the IC $m$-component respectively, $\left(\sum d_{z m}=1\right) ; \mathrm{I}_{K}, \mathrm{I}_{L}, \mathrm{I}_{N}$ - integral indicators of the client, human and innovatie IC $m$-component, respectively, for the observation period $\left(-1 \leq \mathrm{I}_{\mathrm{m}} \leq=1\right)$.

Taking into account the annual values of the indicators according to the IC components, the annual assessment of its integral index for a certain IHE $\left(\mathrm{I}_{\text {IK }}\right)$ was carried out within the limits $[-1,1]$ by the normalized additive convolution (formula 7):

$\mathrm{I}_{\mathrm{IK}}=d_{z K} \times \mathrm{I}_{K}+d_{z L} \times \mathrm{I}_{L}+d_{z N} \times \mathrm{I}_{N}=\sum d_{z m} \times \mathrm{I}_{\mathrm{m}} ;$

The range of integral indicator characteristic values of the development and protection of the IC as a whole and its components for a specific IHE is taken in accordance with the features of the normalization of input $i$ indicators within $[-1,1]$ (Table 1).

Table 1

Value scale of IC integral indicator (component indicators) according to the development and protection levels during the observation period

\begin{tabular}{|c|c|}
\hline Indicator values & Relative level of IC development and protection \\
\hline-1.0 & Critically weak or absent \\
\hline-1.0 до -0.5 & Critically weak \\
\hline Від -0.5 до 0.0 & Moderate weak (low) \\
\hline 0.0 & Medium \\
\hline Від 0.0 до 0.5 & Satisfactory \\
\hline Від 0.5 до 1.0 & High \\
\hline 1.0 & Maximum \\
\hline
\end{tabular}

The main material of the research. Against the backdrop of a competition between all IHEs and difficult working conditions for institutions moved from temporarily occupied territories, the latter have not only a decrease in rating sites, but also a decrease in the integral indicators in the TOP-200 Ukraine rating for 2013 and 2016 (Reitynh VNZ TOP-200 Ukraine). In 2016 out of 6 institutions included in the first thirty rating of 2013, only 2 institutions retained their relative positions, namely Donetsk National Technical University (DonNTU) and Vasyl' Stus Donetsk National University (Vasyl' Stus DonNU) (in QS World University Rankings by Subject 2016-2017 it takes place in group 700+). Luhansk Taras Shevchenko National University (T.Shevchenko LNU) and Volodymyr Dahl East Ukrainian National University (V. Dahl EUNU) significantly worsened their rating positions.

As for Donetsk National Medical University and the V.I. Vernadsky Taurida National University, in addition to a significant deterioration in rating positions, they have a significant decline in the integral indicators. Similar negative tendencies are observed in other moved institutions of higher education.

Thus, the results of the rating comparison indicate that only the most powerful institutions with the status of national ones have been able to maintain their rating and competitive positions in the market of education services. The ratings data for 2013-2016 indicate that the quality index of academic staff was crucial for maintaining their rating positions. Thus, despite the reduction of the education quality index and the effectiveness of international activities because of the known reasons, the growth of the quality index of academic staff did not deteriorate significantly the integral indicator of the rating of the most powerful IHEs: Vasyl' Stus DonNU, DonNTU, V. Dahl EUNU in 2016. In general, the growth of this index is characteristic for 7 out of 12 institutions under the research. Thus, these facts may indicate the existence of the development and protection certain level in innovative and human capital as IC components among institutions moved from the occupied parts of Donetsk and Luhansk regions.

A more accurate assessment of the IC components protection was carried out for the four most powerful IHEs from the moved ones. Using the data from the rectors' reports of these institutions in three years, input groups were formed for the analysis of client, human and innovative capital. After the distribution of input $i$-indicators for incentives and disincentives, their values were the subject to linear normalization in the interval $[-1,1]$ by formulas 1.1 and 1.2, the results of which are given in Table 2 . 
Normalized input i-indicators for the studied groups and IHEs

\begin{tabular}{|c|c|c|c|c|c|c|c|c|c|c|c|c|}
\hline \multirow[t]{2}{*}{$\begin{array}{l}\text { Year } \\
\text { s }\end{array}$} & \multicolumn{4}{|c|}{$\begin{array}{c}\text { Indicator symbols of client } \\
\text { capital }\end{array}$} & \multicolumn{4}{|c|}{$\begin{array}{c}\text { Indicator symbols of human } \\
\text { capital }\end{array}$} & \multicolumn{4}{|c|}{$\begin{array}{c}\text { Indicator symbols of innovative } \\
\text { capital }\end{array}$} \\
\hline & $K_{1 \text { norm }}$ & $K_{2 \text { norm }}$ & $K_{3 \text { norm }}$ & $K_{4 \text { norm }}$ & $L_{1 \text { norm }}$ & $L_{2 \text { нпотm }}$ & $L_{3 \text { нпоrт }}$ & $L_{4 \text { norm }}$ & $N_{1 \text { norm }}$ & $N_{2}$ поrmм & $N_{3 \text { norm }}$ & $N_{4 \text { norm }}$ \\
\hline
\end{tabular}

Donetsk National Technical University (DonNTU)

\begin{tabular}{|c|c|c|c|c|c|c|c|c|c|c|c|c|}
\hline $\begin{array}{c}2013 / \\
2014\end{array}$ & 1 & -1 & 1 & 1 & -1 & -1 & -1 & -1 & 1 & -1 & -1 & 1 \\
\hline $\begin{array}{l}2014 / \\
2015\end{array}$ & -0.6559 & -0.3120 & 0.7942 & -1 & -0.8421 & 0.4410 & 0.5503 & -0.4106 & -0.3793 & -0.5695 & 0.3333 & -1 \\
\hline $\begin{array}{l}2015 / \\
2016\end{array}$ & -1 & 1 & -1 & -0.0906 & 1 & 1 & 1 & 1 & -1 & 1 & 1 & -0.7855 \\
\hline
\end{tabular}

Vasyl' Stus Donetsk National University (Vasyl'Stus DonNU)

\begin{tabular}{|c|c|c|c|c|c|c|c|c|c|c|c|c|}
\hline $\begin{array}{c}2013 / \\
2014\end{array}$ & 0.8415 & -1 & -1 & $\begin{array}{c}- \\
0.22608\end{array}$ & 1 & 0.4432 & 0.7217 & -1 & 1 & 1 & -1 & 1 \\
\hline $\begin{array}{c}2014 / \\
2015\end{array}$ & -1 & -0.3099 & 0.6630 & -1 & 1 & 1 & 1 & 1 & -1 & 0.5434 & -0.3333 & -0.4018 \\
\hline $\begin{array}{c}2015 / \\
2016\end{array}$ & 1 & 1 & 1 & 1 & -1 & -1 & -1 & -0.0335 & -0.9220 & -1 & 1 & -1 \\
\hline
\end{tabular}

Volodymyr Dahl East Ukrainian National University (V. Dahl EUNU)

\begin{tabular}{|c|c|c|c|c|c|c|c|c|c|c|c|c|}
\hline $\begin{array}{c}2013 / \\
2014\end{array}$ & 0.9236 & 1 & 1 & -1 & 1 & -1 & -1 & -1 & 0.4499 & -1 & -1 & 1 \\
\hline $\begin{array}{c}2014 / \\
2015\end{array}$ & -1 & 0.2183 & -0.3467 & -0.7998 & 1 & -0.5281 & -0.2710 & -0.9380 & -1 & 0.1968 & -0.6000 & -1 \\
\hline $\begin{array}{c}2015 / \\
2016\end{array}$ & 1 & -1 & -1 & 1 & -1 & 1 & 1 & 1 & 1 & 1 & 1 & 0.2277 \\
\hline
\end{tabular}

Luhansk Taras Shevchenko National University (T.Shevchenko LNU)

\begin{tabular}{|c|c|c|c|c|c|c|c|c|c|c|c|c|}
\hline $\begin{array}{c}2013 / \\
2014\end{array}$ & $\begin{array}{c}- \\
0.4380\end{array}$ & 1 & 1 & -1 & 1 & $\begin{array}{c}- \\
0.5198\end{array}$ & 0.1861 & -1 & $\begin{array}{c}- \\
0.9355\end{array}$ & -1 & -1 & -1 \\
\hline $\begin{array}{l}2014 / \\
2015\end{array}$ & -1 & -1 & $0 . \overline{-}$ & 1 & 1 & -1 & -1 & 0.1345 & 1 & 1 & 1 & 0.3988 \\
\hline $\begin{array}{l}2015 / \\
2016 \\
\end{array}$ & 1 & $\begin{array}{c}- \\
0.2266 \\
\end{array}$ & -1 & 0.7853 & -1 & 1 & 1 & 1 & -1 & $\begin{array}{c}- \\
0.8431 \\
\end{array}$ & 1 & 1 \\
\hline
\end{tabular}

Using the factor analysis of the main components method, the input $\mathrm{i}$-indicators were converted to the factor $\mathrm{y}=1$ and the factor $\mathrm{y}=2$ (Table 3 ). At the same time, for all institutions, the indicators of client capital immediately form the factors 1 and 2, except for the number of students per one full-time academic worker, which suggests the relative continuity of this ratio and the possibility of using it as a universal indicator in the assessment of client capital. On the other hand, the inclusion of indicators of human and innovative capital in one factor (component) in almost all cases requires certain studies as for the completeness and content of the relevant indicators in order to eliminate the possible one-sided analysis of the component development process.

Based on the normalized values of the inputs $i$-indicators (Table 2) and the results of the factor loadings research in Table 3 the weight of the $i y$-indicators is calculated (input $i$-indicators grouped by $y$-factors) by the formula 2 . The calculation results of indicators for $i y$-indicators according to formulas 3.1-3.3 are presented respectively for client capital in Table 4, for human capital - in Table 5, for innovative capital - in Table 6.

Table 3

Research results of the $i$-indicator factor loads and determination of iy-indicators

\begin{tabular}{|c|c|c|c|c|c|c|c|c|c|c|c|}
\hline \multicolumn{4}{|c|}{ Client capital indicators } & \multicolumn{9}{c|}{ Human capital indicators } & \multicolumn{3}{c|}{ Innovative capital indicators } \\
\hline$K_{i}$ & $\begin{array}{c}\text { Factor } \\
1\end{array}$ & Factor 2 & $\begin{array}{c}\text { Weight } \\
\text { factor }\end{array}$ & $L_{i}$ & $\begin{array}{c}\text { Factor } \\
1\end{array}$ & $\begin{array}{c}\text { Factor } \\
2\end{array}$ & Weight factor & $N_{i}$ & $\begin{array}{c}\text { Factor } \\
1\end{array}$ & $\begin{array}{c}\text { Factor } \\
2\end{array}$ & $\begin{array}{c}\text { Weight } \\
\text { factor }\end{array}$ \\
\hline \multicolumn{8}{|c|}{ Donetsk National Technical University (DonNTU) } \\
\hline$K_{1}$ & $-0,9706$ & $-0,2405$ & 0,2199 & $L_{1}$ & $-0,8827$ & & 0,2390 & $N_{1}$ & 0,9995 & & 0,2443 \\
\hline$K_{2}$ & 0,9561 & $-0,2929$ & 0,2894 & $L_{2}$ & 0,8838 & & 0,2394 & $N_{2}$ & $-0,8768$ & 0,2318 \\
\hline$K_{3}$ & $-0,8530$ & 0,5218 & 0,2582 & $L_{3}$ & $-0,9635$ & & 0,2608 & $N_{3}$ & $-1,0000$ & 0,2643 \\
\hline
\end{tabular}




\begin{tabular}{|c|c|c|c|c|c|c|c|c|c|c|c|}
\hline$K_{4}$ & $-0,6403$ & $-0,7680$ & 0,2325 & $L_{4}$ & $-0,9639$ & & 0,2608 & $N_{4}$ & 0,9058 & & 0,2596 \\
\hline \multicolumn{3}{|c|}{$\begin{array}{l}\text { The share of total dispersion } \\
\qquad \operatorname{Var}_{i y}\end{array}$} & \multirow[t]{2}{*}{1.0000} & \multicolumn{3}{|c|}{$\begin{array}{l}\text { The share of total } \\
\text { dispersion } \operatorname{Var}_{i y}\end{array}$} & \multirow[t]{2}{*}{1.0000} & \multicolumn{3}{|c|}{$\begin{array}{l}\text { The share of total } \\
\text { dispersionsx } \operatorname{Var}_{i y}\end{array}$} & \multirow[t]{2}{*}{1.0000} \\
\hline & 0,7858 & 0,2514 & & & 0,8544 & - & & & 0,8971 & - & \\
\hline \multicolumn{12}{|c|}{ Vasyl' Stus Donetsk National University (Vasyl'Stus DonNU) } \\
\hline$K_{1}$ & $-0,5695$ & 0,8220 & 0,1807 & $L_{1}$ & $-0,9974$ & $-0,0718$ & 0,3014 & $N_{1}$ & 0,8985 & & 0,2402 \\
\hline$K_{2}$ & $-0,9368$ & $-0,3499$ & 0,3251 & $L_{2}$ & $-0,9798$ & 0,1999 & 0,2960 & $N_{2}$ & 0,9180 & & 0,2454 \\
\hline$K_{3}$ & $-0,6215$ & $-0,7834$ & 0,1723 & $L_{3}$ & $-0,9984$ & 0,0570 & 0,3017 & $N_{3}$ & $-0,9571$ & & 0,2559 \\
\hline$K_{4}$ & $-0,9276$ & 0,3736 & 0,3219 & $L_{4}$ & 0,1843 & 0,9829 & 0,1009 & $N_{4}$ & 0,9668 & & 0,2585 \\
\hline \multicolumn{3}{|c|}{$\begin{array}{l}\text { The share of total } \\
\text { dispersionVar }\end{array}$} & \multirow[t]{2}{*}{1.0000} & \multicolumn{3}{|c|}{$\begin{array}{l}\text { The share of total } \\
\text { dispersionVar } i y\end{array}$} & \multirow[t]{2}{*}{1.0000} & \multicolumn{3}{|c|}{$\begin{array}{l}\text { The share of total } \\
\text { dispersionVar }{ }_{i y}\end{array}$} & \multirow[t]{2}{*}{1.0000} \\
\hline & 0,6121 & 0,3879 & & & 0,7464 & 0,2536 & & & 0,8752 & & \\
\hline \multicolumn{12}{|c|}{ Volodymyr Dahl East Ukrainian National University (V. Dahl EUNU) } \\
\hline$K_{1}$ & 0,2421 & 0,9702 & 0,1196 & $L_{1}$ & 0,9880 & & 0,2498 & $N_{1}$ & $-0,6197$ & 0,7848 & 0,1994 \\
\hline$K_{2}$ & $-0,9964$ & 0,0854 & 0,3042 & $L_{2}$ & $-0,9974$ & & 0,2522 & $N_{2}$ & $-0,8718$ & $-0,4850$ & 0,2548 \\
\hline$K_{3}$ & $-0,9178$ & 0,3971 & 0,2792 & $L_{3}$ & $-0,9773$ & & 0,2421 & $N_{3}$ & $-0,9979$ & $-0,0654$ & 0,2916 \\
\hline$K_{4}$ & 0,9755 & 0,2200 & 0,2970 & $L_{4}$ & $-0,9918$ & & 0,2559 & $N_{4}$ & $-0,0060$ & 0,9999 & 0,2542 \\
\hline \multicolumn{3}{|c|}{$\begin{array}{l}\text { The share of total } \\
\text { dispersion } \operatorname{Var}_{i y}\end{array}$} & \multirow[t]{2}{*}{1.0000} & \multicolumn{3}{|c|}{$\begin{array}{l}\text { The share of total } \\
\text { dispersion } \operatorname{Var}_{i y}\end{array}$} & \multirow[t]{2}{*}{1.0000} & \multicolumn{3}{|c|}{$\begin{array}{l}\text { The share of total } \\
\text { dispersion } \operatorname{Var}_{i y}\end{array}$} & \multirow[t]{2}{*}{1.0000} \\
\hline & 0,7113 & 0,2887 & & & 0,9775 & - & & & 0,5349 & 0,4651 & \\
\hline \multicolumn{12}{|c|}{ Luhansk Taras Shevchenko National University (T.Shevchenko LNU) } \\
\hline$K_{1}$ & 0,2976 & $-0,9547$ & 0,0759 & $L_{1}$ & 0,9959 & & 0,2756 & $N_{1}$ & $-0,8179$ & - & 0,2472 \\
\hline$K_{2}$ & $-0,9013$ & $-0,4332$ & 0,2765 & $L_{2}$ & $-0,9900$ & & 0,2739 & $N_{2}$ & $-0,8708$ & - & 0,2632 \\
\hline$K_{3}$ & $-0,9640$ & 0,2659 & 0,2958 & $L_{3}$ & $-0,8575$ & & 0,2373 & $N_{3}$ & $-0,8949$ & - & 0,2705 \\
\hline$K_{4}$ & 0,9884 & 0,1518 & 0,3518 & $L_{4}$ & $-0,7704$ & & 0,2132 & $N_{4}$ & $-0,7249$ & - & 0,2191 \\
\hline \multicolumn{3}{|c|}{$\begin{array}{l}\text { The share of total } \\
\text { dispersion } \text { Var }_{i y}\end{array}$} & \multirow[t]{2}{*}{1.0000} & \multicolumn{3}{|c|}{$\begin{array}{l}\text { The share of total } \\
\text { dispersion } V a r_{i y}\end{array}$} & \multirow[t]{2}{*}{1.0000} & \multicolumn{3}{|c|}{$\begin{array}{l}\text { The share of total } \\
\text { dispersion } \operatorname{Var}_{i y}\end{array}$} & \multirow[t]{2}{*}{1.0000} \\
\hline & 0,7018 & 0,2982 & & & 0,8252 & - & & & 0.6884 & - & \\
\hline
\end{tabular}

According to the formula 4.1 in Table 4 , the calculation of client capital integral indicators was performed for the universities under research.

Table 4

Indicator calculations for iy-indicators and integral indicator of client capital development and protection

\begin{tabular}{|c|c|c|c|c|c|c|}
\hline \multirow[b]{2}{*}{ IHE } & \multirow{2}{*}{ Years } & \multicolumn{4}{|c|}{ Integral indicator } & \multirow{2}{*}{$\begin{array}{l}\text { Integral indicator of client } \\
\text { capital development and } \\
\text { protection }\end{array}$} \\
\hline & & $K_{1}$ & $K_{2}$ & $K_{3}$ & $K_{4}$ & \\
\hline \multirow{3}{*}{$\begin{array}{c}\text { Luhansk Taras Shevchenko } \\
\text { National University } \\
\text { (T.Shevchenko LNU) }\end{array}$} & $2013 / 2014$ & $-0,0332$ & 0,2765 & 0,2958 & $-0,3518$ & 0,1873 \\
\hline & $2014 / 2015$ & $-0,0759$ & $-0,2765$ & $-0,1038$ & 0,3518 & $-0,1044$ \\
\hline & $2015 / 2016$ & 0,0759 & $-0,0627$ & $-0,2958$ & 0,2763 & $-0,0063$ \\
\hline \multirow{3}{*}{$\begin{array}{c}\text { Volodymyr Dahl East } \\
\text { Ukrainian National } \\
\text { University (V. Dahl EUNU) }\end{array}$} & $2013 / 2014$ & 0,1105 & 0,3042 & 0,2792 & $-0,297$ & 0,3969 \\
\hline & $2014 / 2015$ & $-0,1196$ & 0,0664 & $-0,0968$ & $-0,2375$ & $-0,3875$ \\
\hline & $2015 / 2016$ & 0,1196 & $-0,3042$ & $-0,2792$ & 0,297 & $-0,1668$ \\
\hline \multirow{3}{*}{$\begin{array}{l}\text { Vasyl' Stus Donetsk } \\
\text { National University } \\
\text { (Vasyl'Stus DonNU) }\end{array}$} & $2013 / 2014$ & 0,1521 & $-0,3251$ & $-0,1723$ & $-0,0727$ & $-0,4181$ \\
\hline & $2014 / 2015$ & $-0,1807$ & $-0,1007$ & 0,1142 & $-0,3219$ & $-0,4891$ \\
\hline & $2015 / 2016$ & 0,1807 & 0,3251 & 0,1723 & 0,3219 & 1,0000 \\
\hline \multirow{3}{*}{$\begin{array}{l}\text { Donetsk National Technical } \\
\text { University (DonNTU) }\end{array}$} & $2013 / 2014$ & 0,2199 & $-0,2894$ & 0,2582 & 0,2325 & 0,4212 \\
\hline & $2014 / 2015$ & $-0,1442$ & $-0,0903$ & 0,2051 & $-0,2325$ & $-0,2620$ \\
\hline & $2015 / 2016$ & $-0,2199$ & 0,2894 & $-0,2582$ & $-0,0211$ & $-0,2098$ \\
\hline
\end{tabular}

According to the formula 4.2 in Table 5, the calculation of human capital integral indicators for the researched universities was also carried out. 
Indicator calculations for iy-indicators and integral indicator of human capital development and protection

\begin{tabular}{|c|c|c|c|c|c|c|}
\hline \multirow{2}{*}{ IHE } & \multirow{2}{*}{ Years } & \multicolumn{3}{|c|}{ Integral indicator } & $\begin{array}{c}\text { Integral indicator of human } \\
\text { capital development and } \\
\text { protection }\end{array}$ \\
\cline { 3 - 7 } & & $L_{1}$ & $L_{2}$ & $L_{3}$ & $L_{4}$ & 0,1365 \\
\hline \multirow{2}{*}{$\begin{array}{c}\text { Luhansk Taras } \\
\text { Shevchenko } \\
\text { National University } \\
\text { (T.Shevchenko } \\
\text { LNU) }\end{array}$} & $2013 / 2014$ & 0,2756 & $-0,1423$ & 0,2165 & $-0,2132$ & 0,2470 \\
\cline { 2 - 7 } & $2014 / 2015$ & 0,2756 & $-0,2739$ & 0,2166 & 0,02868 & 0,4282 \\
\cline { 2 - 7 } & $2015 / 2016$ & $-0,2756$ & 0,2739 & 0,2167 & 0,2132 & $-0,0415$ \\
\hline $\begin{array}{c}\text { Volodymyr Dahl } \\
\text { East Ukrainian } \\
\text { National University } \\
\text { (V. Dahl EUNU) }\end{array}$ & $2013 / 2014$ & 0,2498 & $-0,2522$ & 0,2168 & $-0,2559$ & 0,0935 \\
\cline { 2 - 7 } & $2014 / 2015$ & 0,2498 & $-0,133187$ & 0,2169 & $-0,240034$ & 0,4753 \\
\hline $\begin{array}{c}\text { Vasyl' Stus Donetsk } \\
\text { National University } \\
\text { (Vasyl'Stus DonNU) }\end{array}$ & $2015 / 2016$ & $-0,2498$ & 0,2522 & 0,217 & 0,2559 & 0,5488 \\
\cline { 2 - 7 } & $2014 / 2015$ & 0,3014 & 0,296 & 0,2521 & 0,1009 & 0,9504 \\
\cline { 2 - 7 } & $2015 / 2016$ & $-0,3014$ & $-0,296$ & $-0,3017$ & $-0,0034$ & $-0,9025$ \\
\hline $\begin{array}{c}\text { Donetsk National } \\
\text { Technical University } \\
\text { (DonNTU) }\end{array}$ & $2013 / 2014$ & $-0,2390$ & $-0,2394$ & $-0,2608$ & $-0,2608$ & $-1,0000$ \\
\cline { 2 - 7 } & $2014 / 2015$ & $-0,2013$ & 0,1056 & 0,1435 & $-0,1071$ & $-0,0593$ \\
\cline { 2 - 7 } & $2015 / 2016$ & 0,2390 & 0,2394 & 0,2608 & 0,2608 & 1,0000 \\
\hline
\end{tabular}

According to the formula 4.3 in Table 6 , the calculation of innovative capital integral indicators for the researched universities was also performed.

Indicator calculations for iy-indicators and integral indicator of innovative capital development and

Table 6 protection

\begin{tabular}{|c|c|c|c|c|c|c|}
\hline \multirow{2}{*}{ IHE } & \multirow{2}{*}{ Years } & \multicolumn{4}{|c|}{ Integral indicator } & $\begin{array}{c}\text { Integral indicator of innovative } \\
\text { capital development and } \\
\text { protection }\end{array}$ \\
\cline { 2 - 7 } & & $N_{1}$ & $N_{2}$ & $N_{3}$ & $N_{4}$ & $-0,9841$ \\
\hline $\begin{array}{c}\text { Luhansk Taras } \\
\text { Shevchenko National } \\
\begin{array}{c}\text { University } \\
\text { (T.Shevchenko } \\
\text { LNU) }\end{array}\end{array}$ & $2013 / 2014$ & $-0,2313$ & $-0,2632$ & $-0,2705$ & $-0,2191$ & 0,8683 \\
\cline { 2 - 7 } & $2014 / 2015$ & 0,2472 & 0,2632 & 0,2705 & 0,0873 & 0,0205 \\
\hline $\begin{array}{c}\text { Volodymyr Dahl } \\
\text { East Ukrainian } \\
\text { National University } \\
\text { (V. Dahl EUNU) }\end{array}$ & $2013 / 2016$ & $-0,2472$ & $-0,2219$ & 0,2705 & 0,2191 & $-0,2025$ \\
\cline { 2 - 7 } & $2014 / 2015$ & $-0,1994$ & 0,0501 & $-0,1749$ & $-0,2542$ & $-0,5784$ \\
\hline $\begin{array}{c}\text { Vasyl' Stus Donetsk } \\
\text { National University } \\
\text { (Vasyl'Stus DonNU) }\end{array}$ & $2013 / 2014$ & 0,2402 & 0,2454 & $-0,256$ & 0,2585 & 0,80367 \\
\cline { 2 - 7 } & $2014 / 2015$ & $-0,2402$ & 0,1333 & $-0,0853$ & $-0,1039$ & 0,4882 \\
\hline & $2015 / 2016$ & $-0,2214$ & $-0,2454$ & 0,2559 & $-0,2585$ & $-0,2960$ \\
\hline $\begin{array}{c}\text { Donetsk National } \\
\text { Technical University } \\
\text { (DonNTU) }\end{array}$ & $2013 / 2014$ & 0,2443 & $-0,2318$ & $-0,2643$ & 0,2596 & $-0,4694$ \\
\cline { 2 - 7 } & $2014 / 2015$ & $-0,0927$ & $-0,1320$ & 0,0881 & $-0,2596$ & 0,0078 \\
\cline { 2 - 6 } & $2015 / 2016$ & $-0,2443$ & 0,2318 & 0,2643 & $-0,2039$ & $-0,3962$ \\
\hline
\end{tabular}

The study of the IC development and protection level was continued by conducting a factor analysis of the integral indicators of IC components for each institution. For integral indicators $\mathrm{I}_{K}, \mathrm{I}_{L}$ and $\mathrm{I}_{N}$ after grouping according to $z$-components, their weight coefficients (formula 5) and corresponding indicators (formula 6.1-6.3) were calculated. Taking into account the values of the latter through the additive convolution, the integral indicator values of the IC as a whole for a certain IHE $\left(\mathrm{I}_{\mathrm{IK}}\right)$ were obtained (Table 7). 
Factor analysis results of integral indicators of IC components and integral indicator calculations of IC development and protection of a certain IHE

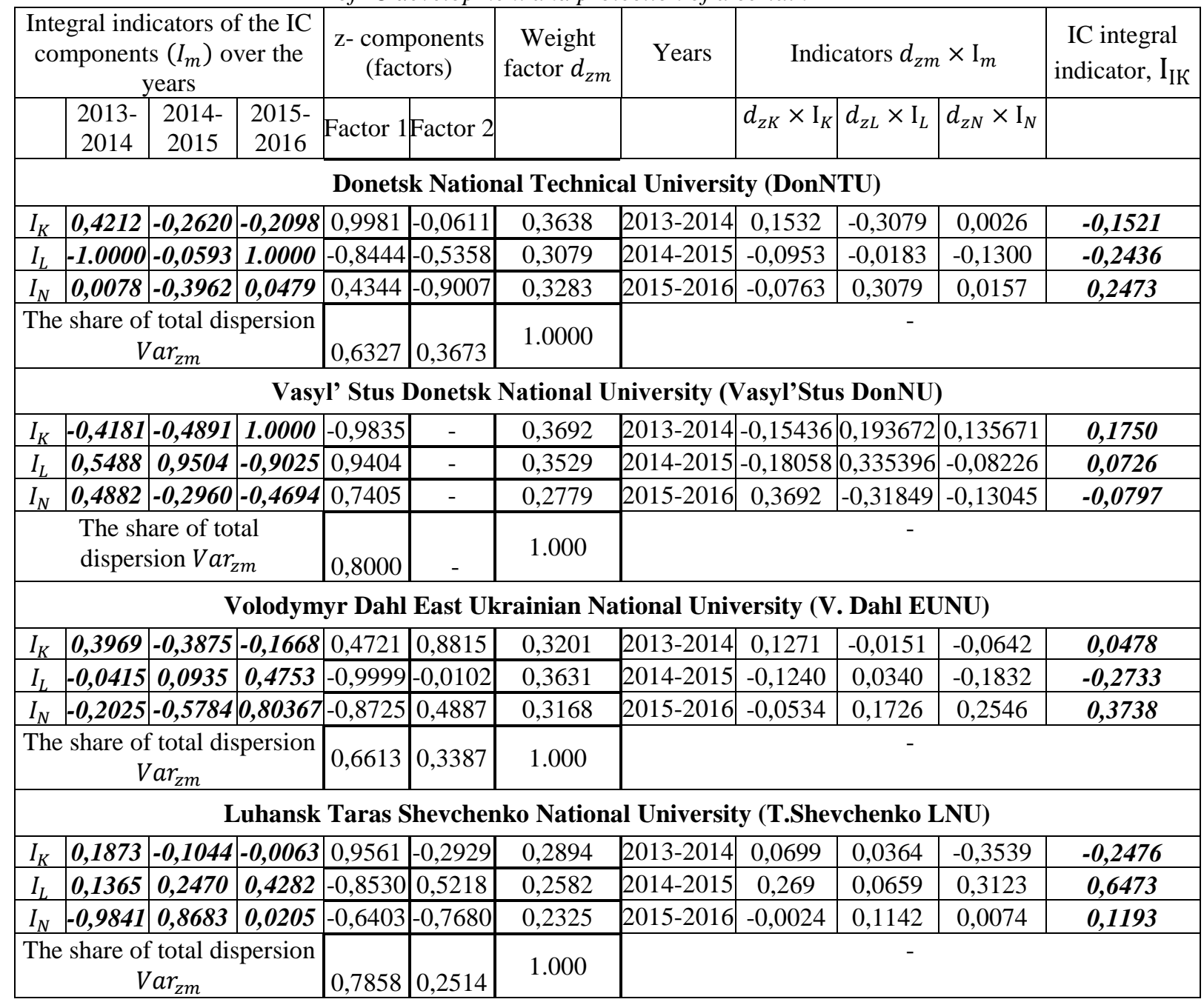

Findings. The dynamics handling of the integral indicators of IC development and protection over the years has been confirmed by the real tendencies in the activity of the IHEs after their forced territorial movement. At the end of the observation period, the level of client capital protection had a positive dynamics only for Vasyl'Stus DonNU. It was negative for all other universities. At the same time, the level of client capital development and protection can be characterized as moderate weak (low), which showed the appropriate ability to restore or not to lose the contingent of students.

The opposite situation has developed with the level of human capital development and protection. At the end of the analyzed period, in all universities, except Vasyl' Stus DonNU, the maximum (in DonNTU) and satisfactory level is marked. This situation is explained by significant losses of human capital in Vasyl' Stus DonNU and lack of sufficient resources for its relatively quick recovery. So, unlike Vasyl' Stus DonNU, the maximum value of this indicator in DonNTU was ensured, despite substantial losses of human resources in 2014, by an increase in human capital at the expense of human resources of their affiliates (colleges).

The protection level of innovative capital reflects the ability of institutions to restore or maintain the indicators of innovative and scientific activity. At the end of the observation period it was: high for the V. Dahl EUNU due to the development and training of full-time academic staff (the number of defended works for obtaining a scientific degree, the number of internships abroad and the number of patents (copyrights) per one full-time academic worker); satisfactory for DonNTU and T.Shevchenko LNU. A relative decline in innovative activity indicators at Vasyl' Stus DonNU determined the corresponding deterioration of the integral indicator along with the modestly weak level of innovation capital development and protection.

Thus, at the end of the period 2013-2016, the three universities that ranked the best positions in TOP-200 Ukraine ranking (DonNTU, Vasyl' Stus DonNU, V. Dahl EUNU) had various levels of development and protection of different IC components over the years. But 2-3 years later, after the forced territorial movement and renewal of work in force majeure, these three universities managed to build noticeably at least one of the IC components. This is evidenced by the significance at the level 1.0 of the human capital integral indicator in 
DonNTU and the client capital integral indicator at Vasyl'Stus DonNU, as well as at the level of 0.8 innovative capital integral indicator at V. Dahl EUNU.

Despite the sharp fluctuation of the integral values of the IC components from - 0.9 to 1.0, each university has the same character of development of the human and innovative intellectual capital component. Thus, the development nature of human and innovative capital in all IHEs was simultaneously positive or at the same time negative. A similar pattern is confirmed by studies in the activities of industrial companies (Andreeva \& Garanina, 2017) and financial institutions (Ayub et al., 2017).

Conclusion. The proposed method for determining the dynamics of development and protection of the IC and its components is universal and may take into account various combinations of key and additional indicators, including a balanced system of indicators (Breus S. \& Khaustova Ye. 2016). The results of its use can become the basis for the development and forecasting of the measures to build individual IC components as public and private education institutions. It makes it possible to have comparative analysis of indicators of either one institution in dynamics, or group of institutions. The scientific novelty of the method lies in the possibility of conducting a nonfinancial analysis of the IC and its components within budget institutions or non-profit organizations, as well as eliminating the subjectivity of the results, which is typical for expert methods with the score scale (Kozhushko, 2016). The expediency of using the possibilities of the factor method to construct a model for the IC development of the institution of higher education is the subject of further research.

\section{Список використаної літератури:}

1. Andreeva T. Intellectual Capital and Its Impact on the Financial Performance of Russian Manufacturing Companies / T.Andreeva, T.Garanina // Foresight and sti governance. - 2017. - Iss. 11 (1), Pp. 31-40.

2. Ayub U. Linking Human Capital and Organisational Innovative Capabilities of Financial Institutions: Evidence from a Developing Country of South Asia / U.Ayub, A.Kausar, M.Qadri // Journal of information \& knowledge management. - 2017. - Iss. 16 (4). - P. 10.

3. Breus S. Vykorystannia zbalansovanoi systemy pokaznykiv u diialnosti vyshchykh navchalnykh zakladiv / S.Breus, Ye. Khaustova // Aktualni problemy ekonomiky. - 2016. - No. 9 (183). - Pp. 109-116. - Acces mode : http://nbuv.gov.ua/UJRN/ape_2016_9_15.

4. Impact of intellectual capital on corporate performance: evidence from the Arab region / V.Dzenopoljac, C.Yaacoub, N.Elkanj, N.Bontis // Journal of Intellectual Capital. - Vol. 18. - Iss.4. - Pp. 884-903. - Acces mode : https://doi.org/10.1108/JIC-01-2017-0014.

5. Herv'e Abdi Normalizing Data. In Neil Salkind (Ed.) / Abdi Herv'e // Encyclopedia of Research Design.Thousand Oaks. - CA : Sage. - 2010. - Acces mode : https://www.utdallas.edu/ herve/abdiNormalizing2010-pretty.

6. Kozhushko O. Substantiation of indicators for assessing the level of protection of intellectual capital of an industrial enterprise / O.Kozhushko. - Kyiv : Publishing Centre of educational literture, 2016. - 182 p.

7. Identifying future directions for IC research in education: a literature review / B.Marco, D.John, M.Francesca, T.Paolo // Journal of Intellectual Capital. - 2018. - Vol. 19. - Iss. 1. - Pp. 10-33.

8. Pedro Eu. Intellectual capital and performance: Taxonomy of components and multi-dimensional analysis axes / Eu.Pedro, J.Leitão, H.Alves // Journal of Intellectual Capital. - 2018. - Vol. 19. - Iss. 2. - Pp. 407-452.

9. Pro zatverdzhennia Metodyky rozrakhunku intehralnykh rehionalnykh indeksiv ekonomichnoho rozvytku. - Acces mode : http://uazakon.com/documents/date_1a/pg_ibcnog/index.htm.

10. Reitynh VNZ TOP-200 Ukraina 2013/2014. - Acces mode $:$ http://www.euroosvita.net/index.php/?category=1\&id=3281.

11. Reitynh VNZ TOP-200 Ukraina 2014/2015. - Acces mode : http://www.euroosvita.net/index.php/?category=1\&id=4069.

12. Reitynh VNZ TOP-200 Ukraina 2015/2016. - Acces mode : http://www.euroosvita.net/index.php/?category=1\&id=4757.

13. Тутова О.В. Вимірювання рівня людського розвитку за допомогою методів агрегування / О.В. Тутова // Економіко-математичне моделювання соціально-економічних систем : збірник наукових праць. - Вип. 20. Київ : Міжнародний науково-навчальний центр інформаційних технологій та систем НАН України і МОН України. - 2015. - 379 с. - C. 343-355. - Acces mode : http://nbuv.gov.ua/UJRN/emmses_2015_20_21.

14. Vladimír Bureš Self-assessment of intellectual capital in an organisation: Inclusion of internal view, dynamics, and topicality / Vladimír Bureš // Journal of Intellectual Capital. - 2018. - Vol. 19. - Iss. 2. - Pp.387406. - Acces mode : https://doi.org/10.1108/JIC-12-2016-0135.

15. Zvit V. Dahl EUNU, Ph.D., professor O.V. Porkoyan. - Acces mode : http://snu.edu.ua/wpcontent/uploads/2017/01/Zvit2016.pdf.

16. Zvit v.o rektora DONNTY Ljashka Ja.O. pro vykonannja obov'jazkiv za 2015 rik. - Acces mode : http://donntu.edu.ua/2016/publ/zvit_rektor2015.pdf.

17. Zvit v.o rektora DONNTY Ljashka Ja.O. pro vykonannja obov'jazkiv za 2016 rik. - Acces mode : http://donntu.edu.ua/wp-content/uploads/2015/04/zvit_rektor2016.pdf.

18. Zvit rektora DonNU imeni Vasilja Stusa Grinjuka R.F. : pro robotu kolektivu universitetu za 2016 rik ta perspektivni zavdannja rozvitku. - Acces mode : http://www.donnu.edu.ua/uk-ua/prozorist-ta-informatsiyna-vidkritist/Pages/default.aspx.

19. Zvit rektora DonNU imeni Vasilja Stusa Grinjuka R.F. : pro robotu kolektivu universitetu za 2017 rik ta perspektivni zavdannja rozvitku. - Acces mode : http://www.donnu.edu.ua/uk-ua/prozorist-ta-informatsiynavidkritist/Pages/default.aspx.

20. Zvit rektora Savchenka S.V. DZ «Lugans'kij nacional'nij universitet imeni Tarasa Shevchenka» za period z sichnja 2016 roku po sichen' 2017 roku. - Starobil's'k : Publishing State institution T.Shevchenko : LNU, 139 p. 


\section{References:}

1. Andreeva, T. and Garanina, T. (2017), «Intellectual Capital and Its Impact on the Financial Performance of Russian Manufacturing Companies», Foresight and sti governance, Iss. 11 (1), Pp. 31-40.

2. Ayub, U., Kausar, A. and Qadri, M. (2017), «Linking Human Capital and Organisational Innovative Capabilities of Financial Institutions: Evidence from a Developing Country of South Asia», Journal of information \& knowledge management, Iss. 16 (4). P. 10.

3. Breus, S. and Khaustova, Ye. (2016), «Vykorystannia zbalansovanoi systemy pokaznykiv u diialnosti vyshchykh navchalnykh zakladiv», Aktualni problemy ekonomiky, No. 9 (183), Pp. 109-116, available at: http://nbuv.gov.ua/UJRN/ape_2016_9_15

4. Dzenopoljac, V., Yaacoub, C., Elkanj, N. and Bontis, N. (2017), «Impact of intellectual capital on corporate performance: evidence from the Arab region», Journal of Intellectual Capital, Vol. 18, Iss.4, Pp. 884-903, available at: https://doi.org/10.1108/JIC-01-2017-0014

5. Herv'e, Abdi (2010), Normalizing Data. In Neil Salkind (Ed.), Encyclopedia of Research Design, Thousand Oaks, CA, Sage, available at: https://www.utdallas.edu/ herve/abdi-Normalizing2010-pretty.

6. Kozhushko, O. (2016), Substantiation of indicators for assessing the level of protection of intellectual capital of an industrial enterprise, Publishing Centre of educational literture, Kyiv, $182 \mathrm{p}$.

7. Marco, B., John, D., Francesca, M. and Paolo, T. (2018), «Identifying future directions for IC research in education: a literature review», Journal of Intellectual Capital, Vol. 19, Iss. 1, Pp.10-33.

8. Pedro, Eu., Leitão, J. and Alves, H. (2018), «Intellectual capital and performance: Taxonomy of components and multi-dimensional analysis axes», Journal of Intellectual Capital, Vol. 19, Iss. 2, Pp. 407-452.

9. Verhovna rada Ukrainy «Pro zatverdzhennia Metodyky rozrakhunku intehralnykh rehionalnykh indeksiv ekonomichnoho rozvytku», available at: http://uazakon.com/documents/date_1a/pg_ibcnog/index.htm

10. Reitynh VNZ TOP-200 Ukraina 2013/2014, available at: http://www.euroosvita.net/index.php/?category=1\&id=3281

11. Reitynh VNZ TOP-200 Ukraina 2014/2015, available at: http://www.euroosvita.net/index.php/?category=1\&id=4069

12. Reitynh VNZ TOP-200 Ukraina 2015/2016, available at: http://www.euroosvita.net/index.php/?category=1\&id=4757

13. Tutova, O.V. (2015), «Vymirjuvannja rivnja ljuds'kogo rozvytky za dopomogoju medodiv agreguvannja», Ekonomiko matematychna modeljuvannja social'no ekonomichyh system, zb. nauk. pracjuju, NAN Ukrai'ny, MON Ukrai'ny, Iss. 20, C. 379, C. 343-355, available at: http://nbuv.gov.ua/UJRN/emmses_2015_20_21

14. Vladimír Bureš, (2018), «Self-assessment of intellectual capital in an organisation: Inclusion of internal view, dynamics, and topicality», Journal of Intellectual Capital, Vol. 19, Iss. 2, Pp. 387-406, available at: https://doi.org/10.1108/JIC-12-2016-0135

15. EDU «Zvit V. Dahl EUNU, Ph.D., professor O.V. Porkoyan», available at: http://snu.edu.ua/wpcontent/uploads/2017/01/Zvit2016.pdf

16. EDU «Zvit v.o rektora DONNTY Ljashka Ja.O. pro vykonannja obov'jazkiv za 2015 rik», available at: http://donntu.edu.ua/2016/publ/zvit_rektor2015.pdf

17. EDU «Zvit v.o rektora DONNTY Ljashka Ja.O. pro vykonannja obov'jazkiv za 2016», available at: http://donntu.edu.ua/wp-content/uploads/2015/04/zvit_rektor2016.pdf

18. EDU «Zvit rektora DonNU imeni Vasilja Stusa Grinjuka R.F. pro robotu kolektivu universitetu za 2016 rik ta perspektivni zavdannja rozvitku», available at: http://www.donnu.edu.ua/uk-ua/prozorist-ta-informatsiynavidkritist/Pages/default.aspx

19. EDU «Zvit rektora DonNU imeni Vasilja Stusa Grinjuka R.F. pro robotu kolektivu universitetu za 2017 rik ta perspektivni zavdannja rozvitku», available at: http://www.donnu.edu.ua/uk-ua/prozorist-ta-informatsiynavidkritist/Pages/default.aspx

20. EDU «Zvit rektora Savchenka S. V. DZ «Lugans'kij nacional'nij universitet imeni Tarasa Shevchenka» za period z sichnja 2016 roku po sichen' 2017 roku, informacijni materiali, Starobil's'k, Publishing State institution T. Shevchenko LNU, $139 \mathrm{p}$.

Хаустова Свгенія Борисівна - кандидат економічних наук, доцент, доцент кафедри обліку і аудиту, Київський національний університет технологій та дизайну.

Наукові інтереси:

- мікроекономіка;

- управління капіталом та інтелектуальними активами.

E-mail: g.haystova@gmail.com.

Денисенко Микола Павлович - доктор економічних наук, професор, професор кафедри бізнесекономіки та туризму, Київський національний університет технологій та дизайну.

Наукові інтереси:

- д дослідження проблем інвестиційно-інноваційної діяльності.

E-mail: profden3@gmail.com. 